\title{
First record of the gray-legged tinamou, Crypturellus duidae, and other poor-soil specialist birds from peatlands in the Putumayo River basin, Loreto, Peru
}

\author{
Francisco A. VÁSQUEZ-ARÉVALO ${ }^{*} \oplus$, Ricardo ZÁRATE-GÓMEZ², Jacob B. SOCOLAR ${ }^{3}$, Juan DÍAZ- \\ ALVÁN $^{4}$, Pedro E. PÉREZ-PEÑA ${ }^{5}$ \\ Universidad Nacional de la Amazonía Peruana (UNAP). Facultad de Ciencias Biológicas. Pebas 5ta Cuadra, lquitos, Maynas, Loreto, Peru \\ Instituto de Investigaciones de la Amazonía Peruana (IIAP), Programa de Investigación en Cambio Climático Desarrollo Territorial y Ambiente, Av. A. Quiñones \\ km 2.5 (lquitos), San Juan Bautista, Maynas, Loreto, Peru \\ Norwegian University of Life Sciences, Universitetstunet 3, 1430 Ås, Norway \\ 4 Universidad Científica del Perú (UCP), Av. A. Quiñones km 2.5 (lquitos), San Juan Bautista, Maynas, Loreto, Peru \\ Instituto de Investigaciones de la Amazonía Peruana (IIAP), Programa de Investigación en Biodiversidad Amazónica, Av. A. Quiñones km 2.5 (lquitos), \\ San Juan Bautista, Maynas, Loreto, Peru \\ * Corresponding author: fvasquezare@gmail.com; (D) https://orcid.org/0000-0002-8177-0757
}

\section{ABSTRACT}

Crypturellus duidae (Tinamidae) is a poor-soil specialist with isolated populations in Amazonia, and is considered restricted to white-sand forest habitats. We report the first record of $C$. duidae in a peatland forest in northern Peru, in the Putumayo River basin. Our record extends the known distribution of $C$. duidae between two disjoint areas of occurrence in Peru and Colombia, and shows its presence in peatland forest, another forest type on nutrient-poor soils. Additionally, we report the presence of other poor-soil specialist bird species that were previously registered in peatlands. Together with the new record of $C$. duidae, these bird records provide evidence of the diversity of poor-soil specialists in peatland forests.

KEYWORDS: Mauritia flexuosa, palm swamps, white-sand forests, Amazonia

\section{Primer registro de la perdiz de pata gris, Crypturellus duidae, y otras aves especialistas de suelos pobres en turberas en la cuenca del Río Putumayo, Loreto, Perú}

\section{RESUMEN}

Crypturellus duidae (Tinamidae) es considerada un ave especialista de suelos pobres, con poblaciones aisladas y restrictas a bosques sobre arena blanca en Amazonía. En este trabajo reportamos el primer registro de $C$. duidae en un bosque de turbera al norte de Perú, en la cuenca del Río Putumayo. Nuestro registro extiende la distribución conocida de $C$. duidae entre dos áreas de ocurrencia disjunta entre Perú y Colombia, y muestra su presencia en bosques de turbera, otro tipo de bosque sobre suelos pobres en nutrientes. Adicionalmente reportamos la presencia de otras aves especialistas de suelos pobres anteriormente registradas en turberas. En conjunto con el nuevo registro de $C$. duidae, esos registros de aves proporcionan evidencia de la diversidad de especialistas de suelos pobres en bosques de turberas.

PALABRAS-CLAVE: Mauritia flexuosa, pantanos de palmeras, bosque sobre arena blanca, Amazonía

In the Loreto region, in the northern Peruvian Amazon, white-sand forests are a distinctive collection of forest types characterized by high stem densities (roughly 1000 stems > $10 \mathrm{~cm}$ DBH per hectare), a canopy as low as $5 \mathrm{~m}$ (GarcíaVillacorta et al. 2003), and a distinctive floristic assemblage dominated by specialist trees (Zárate et al. 2015). The avifauna is also distinctive and includes a variety of specialist species such as Polioptila clementsi Whitney and Álvarez, 2005,
Neopelma chrysocephalum Pelzelm, 1868, Zimmerius villarejoi Álvarez and Whitney, 2001, among others (Álvarez et al. 2012; Álvarez et al. 2013; Borges et al. 2016; Díaz-Alván et al. 2017; Socolar et al. 2018).

The gray-legged tinamou, Crypturellus duidae J.T. Zimmer, 1938 (Tinamidae) is a poorly known species distributed disjunctly on nutrient-poor white-sand forests across northern South America (Schulenberg et al. 2010; BirdLife

CITE AS: Vásquez-Arévalo, F.A.; Zárate-Gómez, R.; Socolar, J.B.; Díaz-Alván,; J; Pérez-Peña, P.E. . 2020. First record of the gray-legged tinamou, Crypturellus duidae, and other poor-soil specialist birds from peatlands in the Putumayo River basin, Loreto, Peru. Acta Amazonica 50: 155-158. 
International 2017; Borges et al. 2017). In Peru, the species is known exclusively from white-sand forests in the Nanay and middle Tigre river basins (Álvarez and Whitney 2003; Díaz-Alván et al. 2017). The species is apparently absent from extensive white-sand forests along the Morona River and south of the Amazonas River (O'Shea et al. 2015; Schmitt et al. 2017).

Recent work in Loreto has documented extensive peatland forests in swampy river floodplains (Draper et al. 2014). Forests that receive floodwaters are frequently dominated by the palm Mauritia flexuosa L.f., while domed ombrotrophic peatland swamps, that receive water and nutrients only from precipitation, and not through connections with water currents, such as minerotrophic peatlands (Lähteenoja et al. 2009), resemble white-sand forests in several important ways, including severe nutrient limitation, stunted physiognomy, and low epiphyte loads (Draper et al. 2014). Moreover, while these forests are severely depauperate in tree species, the few that are present are often shared with white-sand forests and include white-sand specialists (Zárate et al. 2013; Draper et al. 2018). The avifauna of ombrotrophic peatlands also shows clear white-sand affinities. For example, recent records indicate that peatlands along the lower Tigre River, in Loreto-Peru, harbor white-sand specialists (Díaz-Alván et al. 2017).

Here, we report a record of Crypturellus duidae from a peatland forest in the Putumayo River basin in Loreto, Peru. In addition to being the first record of $C$. duidae from a peatland forest, this is the first record of the species in Peru far from white sand and its known occurrence areas in the upper Nanay River basin in Peru and in the Chiribiquete region of Colombia (Álvarez et al. 2003).

From 14 August to 11 September 2017 we surveyed bird communities in peatlands and terra firme forests dominated by the palms Mauritia flexuosa and Oenocarpus bataua Mart., respectively, along the upper Putumayo River, Loreto, Peru. In the vicinity of our sampling site, we assessed habitat in $20 \mathrm{x}$ $50 \mathrm{~m}$ tree plots (Stohlgren et al. 1995; Judd et al. 1999). On 1 September 2017, near the town of Santa Rita, on the Yubineto River, we recorded the distinctive song of Crypturellus duidae from a peatland dominated by $M$. flexuosa $\left(1^{\circ} 00^{\prime} 02.12^{\prime \prime} \mathrm{S}\right.$, $74^{\circ} 19^{\prime} 39.35^{\prime \prime} \mathrm{W}$; Figure 1). The song was recorded at 07;25 a.m.using an LG H502 smartphone and the RecForce II application for Android system. The voice-recording is diagnostic for $C$. duidae and is available in the Xeno Canto library (XC429170, www.xeno-canto.org). In addition to the voice-recorded individual, we detected two further individuals vocalizing nearby.

Habitat at the site consisted of palms with scattered dicot trees growing on waterlogged substrate. The canopy height varied roughly between 12 to $19 \mathrm{~m}$, with emergent trees and palms as tall as $25 \mathrm{~m}$. Stem densities $(\geq 10 \mathrm{~cm} \mathrm{DBH})$ varied between 78 and 96 stems per 0.1 ha, of which 17 to 23 stems
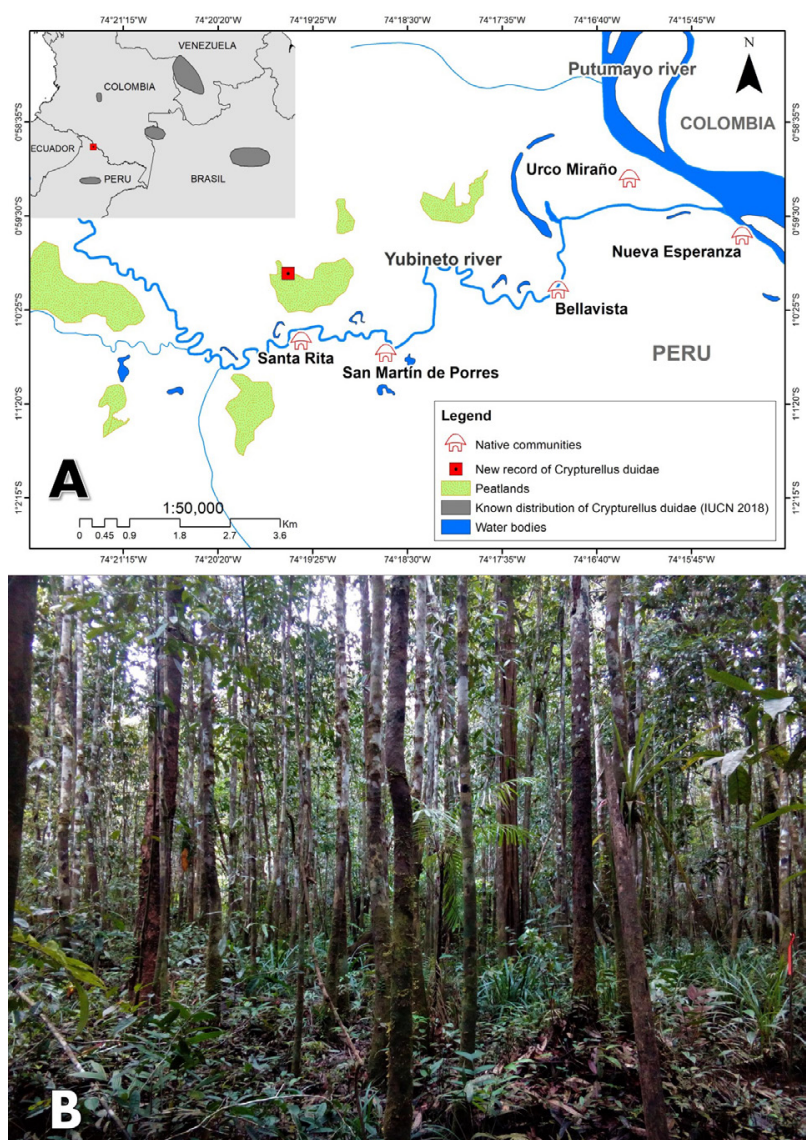

Figure 1. A - Location of the record of the gray-legged tinamou, Crypturellus duidae in the Yubineto River drainage, Putumayo, Loreto Peru. The inset shows the global range of $C$. duidae (based on BirdLife International). B - Image of the habitat in which the gray-legged tinamou was recorded. This figure is in color in the electronic version.

involved the dominant palm $M$. flexuosa. Other common tree species included Oxandra euneura Diels, Euterpe precatoria Mart., Cynometra spruceana Benth., Virola pavonis (A. DC.) A.C. Sm., among others.

Apart from Crypturellus duidae, we recorded in the upper Putumayo study area a number of other bird species with white-sand forest affinity in peatlands, terra firme forests, and non-peatland floodplain forest (Table 1). Our records represent a new habitat and an extension of the known distribution range of $C$. duidae in Peru. Amazonian peatlands are geologically ephemeral formations, with radiocarbon dates for the onset of peat accumulation generally of a few thousand years ago (Lähteenoja et al. 2012; Roucoux et al. 2013). Thus, the ocurrence of $C$. duidae on isolated peatlands in northern Loreto, coupled with the presence of a variety of poor-soil specialist species in the surrounding terra firme, suggests that C. duidae might maintain low-density populations across a vast forest area between known populations near Iquitos, Peru and in Chiribiquete, Colombia. 
Table 1. Poor-soil specialist birds (Álvarez et al. 2013; Borges et al. 2016) registered in the Putumayo River basin in Loreto, Peru. Habitat codes: $F=$ floodplain forest; $P$ = peatland; $T$ = terra firme forest. Previous peatland record = Species was previously registered in peatland forests according to Díaz-Alván et al. (2017).

\begin{tabular}{|c|c|c|c|c|}
\hline Species & Family & Common name & Habitat & $\begin{array}{c}\text { Previous peatland } \\
\text { record }\end{array}$ \\
\hline Nyctibius bracteatus & Nyctibiidae & Rufous Potoo & $\mathrm{F}$ & \\
\hline Trogon rufus & Trogonidae & Black-throated Trogon & $P, T$ & $x$ \\
\hline Galbula dea & Galbulidae & Paradise Jacamar & $\mathrm{T}$ & $x$ \\
\hline Northarchus ordii & Bucconidae & Brown-banded Puffbird & $\mathrm{T}$ & $x$ \\
\hline Megastictus margaritatus & Thamnophilidae & Pearly Antshrike & $\mathrm{T}$ & $x$ \\
\hline Hypocnemis hypoxantha & Thamnophilidae & Yellow-browed Antbird & $F, T$ & \\
\hline Sclerurus rufigularis & Furnariidae & Short-billed Leaftosser & $\mathrm{T}$ & $x$ \\
\hline Deconychura longicauda & Furnariidae & Long-tailed Woodcreeper & T & \\
\hline Lepidocolaptes duidae & Furnariidae & Duida Woodcreeper & T & $x$ \\
\hline Lophotriccus galeatus & Tyrannidae & Helmeted Pygmy-Tyrant & $\mathrm{T}$ & $x$ \\
\hline Conopias parvus & Tyrannidae & Yellow-throated Flycatcher & $F, T$ & $x$ \\
\hline Ramphotrigon ruficauda & Tyrannidae & Rufous-tailed Flatbill & $F, P, T$ & $x$ \\
\hline Attila citriniventris & Tyrannidae & Citron-bellied Attila & $F, P, T$ & $x$ \\
\hline Heterocercus aurantiivertex & Pipridae & Orange-crowned Manakin & $F, P, T$ & $x$ \\
\hline Dixiphia pipra & Pipridae & White-crowned Manakin & $\mathrm{T}$ & $x$ \\
\hline
\end{tabular}

While peatland pole forest (a type of ombrotrophic peatland different in physiognomy and composition of plant species than peatland dominated by M. flexuosa; Draper et al. 2014, 2017) is known to harbor a variety of white-sand specialist birds (Díaz-Alván et al. 2017), our records of $C$. duidae and other poor-soil specialist species recorded on peatlands are the first from peatlands dominated by $M$. flexuosa (peatland palm swamp) (Draper et al. 2014, 2017). Because $M$. flexuosa palm swamps dominate a vast area of northern Peru (Draper et al. 2014), these records suggest that some of these species might be more widely distributed than previously thought.

The mechanisms governing habitat selection for $C$. duidae and other white-sand specialists are not well known. It is perhaps noteworthy that the vast majority of $C$. duidae records from the Nanay basin are from white-sand forests on waterlogged substrates with a deep layer of organic humus ("varillal humedo"; J. Socolar, personal observation), which may affect the foraging or nesting ecology of $C$. duidae. On white-sand, $C$. duidae is often associated with dense understory stands of the palm Euterpe catinga Wallace, which do not exist at the Putumayo site, though its congener $E$. precatoria is relatively common. It is also possible that $C$. duidae is a dietary specialist on fruit or invertebrate resources that are restricted to moist poor-soil forests.

As in Peru, in other countries, C. duidae is considered an indicator species of white-sand forest (Hurd et al. 1995; Borges et al. 2016, 2017). However, there is a previous record of $C$. duidae within the Chiribiquete National Park, in a flooded forest with a structure similar to forests that grow on poor soils (Álvarez et al. 2003). Although it is known that there are peatlands in the Guayana Highland landscape (including the Serranía de Chiribiquete) (Zinck and Huber 2011), it is not known whether the record of $C$. duidae was related to a peatland forest. The presence of species with isolated populations, such as $C$. duidae and other poor-soil specialist birds in the upper Putumayo region suggests the existence of previously unrecognized poor-soil bird assemblages across northernmost Peru, which possibly afford connectivity between populations on the Guianan shield and populations near Iquitos (Socolar et al. 2018).

\section{ACKNOWLEDGMENTS}

We thank the Instituto de Investigaciones de la Amazonía Peruana for funding our fieldwork and the Proyecto Especial Binacional Desarrollo Integral de la Cuenca del Rio Putumayo for support. We thank the entire field team involved in the inventory: Geancarlo Coello, Claudia Ramos, Guillisa Flores, Ian Medina, Jorge Pizarro, Amilcar Ortiz, Victor Vásquez and Kember Mejía. We thank members of the Mashunta, Santa Rita, and Nueva Jerusalen indigenous communities for support in the field. We thank Luis Torres and Marcos Ríos for sharing information about peatlands in Peru, and Surecht Ruiz for assistance in preparing the map in Figure 1. Finally, we thank Claudia Keller, Sergio Borges and two anonymous reviewers for their comments on the manuscript.

\section{REFERENCES}

Álvarez, A.J.; Whitney, B.M. 2003. New distributional records of birds from white-sand forests of the northern Peruvian Amazon, with implications for biogeography of northern South America. Condor, 105: 552-566.

Álvarez, M.; Umaña, A.M.; Mejía, G.D.; Cajiao, J.; von Hildebrand, P.; Gast, F. 2003. Aves del Parque Nacional Natural Serranía de Chiribiquete, Amazonia-Provincia de la Guyana, Colombia. Biota Colombiana, 4: 49-63.

Álvarez, A.J.; Díaz, A.J.; Shany, N. 2012. Avifauna de la Reserva Nacional Allpahuayo Mishana, Loreto. Peru. Cotinga, 34: 61-84. 
Álvarez, A.J.; Metz, M.R.; Fine, P.V.A. 2013. Habitat specialization by birds in western Amazonian white-sand forests. Biotropica, 45: 365-372.

Borges, S.H.; Cornelius, C.; Ribas, C.; Almeida, R.; Guilherme, E.; Aleixo, A.; et al. 2016. What is the avifauna of Amazonian whitesand vegetation? Bird Conservation International, 26: 192-204.

Borges, S.H.; Whittaker, A.; Almeida, R.A.; Cornelius, C.; SantosJr, M.A.; Moreira, M. 2017. Bird records in the northwestern and central portions of the Amazon Basin highlight the needs for inventories and long-term monitoring in the region. Revista Brasileira de Ornitologia, 25: 206-220.

BirdLife International. 2017. Species factsheet: Crypturellus duidae (http://datazone.birdlife.org/species/factsheet/22678213). Accessed on 16 Jan 2020.

Díaz-Alván, J.; Socolar, J.B.; Álvarez, A.J. 2017. The Avifauna of the Río Tigre Basin, Northern Peru. Ornitología Neotropical, 28: $11-21$.

Draper, F.C; Roucoux, K.H.; Lawson, I.T.; Mitchard, E.T.A.; Honorio, C.E.N.; Lähteenoja, O.; Torres, M.L.; Valderrama, S.E.; Zárate, R.; Baker, T.R. 2014. The distribution and amount of carbon in the largest peatland complex in Amazonia. Environmental Research Letters, 9: 1-12.

Draper, F.C; Honorio, C.E.N.; Roucoux, K.H.; Lawson, I.T.; Pitman, N.C.A.; Fine, P.V.A.; et al. 2018. Peatland forests are the least diverse tree communities documented in Amazonia, but contribute to high regional beta-diversity. Ecography, 41: $1256-1269$.

García-Villacorta, R.; Ahuite-Reátegui, M.; Olortegui-Zumaeta, M. 2003. Clasificación de bosques sobre arena blanca de la Zona Reservada Allpahuayo-Mishana. Folia Amazónica, 14: 17-33.

Hurd, F.G.S.; Telleria, J.L.; Díaz, M. 1995. Observaciones sobre la composición, ecología, y zoogeografía de la avifauna de la Sierra de Chiribiquete, Caquetá, Colombia. Caldasia, 17: 481-500.

Judd, W.; Campbell, C.; Kellogg, E.; Stevens, P. 1999. Plant Systematics. A Phylogenetic Approach. Sinauer Associates, Sunderland, Massachusetts. xvi $+464 \mathrm{p}$.

Lähteenoja, O.; Ruokolainen, K.; Schulman, L.; Alvarez, J. 2009. Amazonian floodplains harbour minerotrophic and ombrotrophic peatlands. Catena, 79: 140-145.
Lähteenoja, O.; Reátegui, Y.R.; Räsänen, M.; Torres, D.D.C.; Oinonen, M.; Page, P. 2012. The large Amazonian peatland carbon sink in the subsiding Pastaza-Marañón foreland basin, Peru. Global Change Biology, 18: 164-178.

O’Shea, B.J.; Stotz, D.F.; Saboya, C.P.; Ruelas, I.E. 2015. Birds. In: Pitman, N.A.; Vriesendorp, C.; et al. (Ed.). Peru: Tapiche Blanco. Rapid Biological and Social Inventories Report 27. The Field Museum, Chicago, p.305-320.

Roucoux, K.H.; Lawson, I.T.; Jones, T.D.; Baker, T.R.; Honorio, C.E.N.; Gosling, W.D.; Lähteenoja, O. 2013. Vegetation development in an Amazonian peatland. Palaeogeography, Palaeoclimatology, Palaeoecology, 374: 242-255.

Schmitt, F.; Sané, R.; Thibault, M.; Vásquez, G. 2017. New locality for White-masked Antbird Pithys castaneus and other avian range extensions for dpto. Loreto, Peru. Cotinga, 39: 2-11.

Schulenberg, T.S.; Stotz, D.F.; Lane, D.F.; O’Neill, J.P.; Parker III, T.A. 2010. Birds of Peru: Revised and updated edition. Princeton Univ. Press, Princeton, 664p.

Socolar, J.B.; Díaz-Alván, J.; Saboya, D. P.; Pormara, L.Y.; O’Shea, B.J.; Cubas, S.P.; et al. 2018. Noteworthy bird records from northeastern Peru reveal connectivity and isolation in the western Amazonian avifauna. The Wilson Journal of Ornithology 130: 94-111.

Stohlgren, T.; Falkner, M.; Schell, L. 1995. Modified-Whittaker Nested Vegetation Sampling Method. Vegetatio, 117: 113-121.

Zárate, R.; Mori, T.; Maco, J.T. 2013. Estructura y composición florística de las comunidades vegetales del ámbito de la carretera Iquitos-Nauta, Loreto-Peru. Folia Amazonica, 22: 77-89.

Zárate, R.; Mori, T.; Ramirez, F.; Davila, H.; Gallardo, P.; Cohello, G. 2015. Lista actualizada y clave para la identificación de 219 especies arbóreas de los bosques sobre arena blanca de la Reserva Nacional Allpahuayo Mishana, Loreto, Peru. Acta Amazonica, 45:133-156.

Zinck, J. A.; Huber, O. 2011. Peatlands of the Western Guayana Highlands, Venezuela. Properties and Paleogeographic Significance of Peats. 1st ed. Springer, Heidelberg, Dordrecht, London, New York, 280p.

RECEIVED: $26 / 04 / 2019$

ACCEPTED: $16 / 01 / 2020$

ASSOCIATE EDITOR: Sérgio H. Borges 